BBA 75982

\title{
ISOLATION OF A PROTEIN FROM BEEF LIVER WHICH SPECIFICALLY STIMULATES THE EXCHANGE OF PHOSPHATIDYLCHOLINE*
}

\author{
K. W. A. WIRTZ, H. H. KAMP AND L. L. M. VAN DEENEN \\ Laboratory of Biochemistry, State University of Utrecht, Vondellaan 26, Utrecht (The Netherlands)
}

(Received February 16th, 1972)

\section{SUMMARY}

I. The soluble protein fraction from beef liver contains a protein which stimulates phospholipid exchange. The activity of this protein has been assayed by determining the stimulation of phosphatidylcholine exchange either between ${ }^{32} \mathrm{P}$-labeled mitochondria and microsomes or between mitochondria labeled with $\left[{ }^{14} \mathrm{C}\right]$ phosphatidylcholine and microsomes.

2. The phospholipid exchange protein from beef liver has been purified 3I0-fold with an overall recovery of activity of $15 \%$. $\left(\mathrm{NH}_{4}\right)_{2} \mathrm{SO}_{4}$ precipitation, ion-exchange chromatography on DEAE-Sephadex A-5o and gel filtration on Sephadex G-75 and Sephadex G-50 were used.

3. The isolated phospholipid exchange protein stimulated specifically the exchange of phosphatidylcholine between mitochondria and microsomes. This specificity was also apparent in the phospholipid exchange between microsomes and liposomes consisting of egg yolk phosphatidylcholine and between mitochondria and liposomes consisting of egg yolk phosphatidylcholine $(70$ mole $\%)$ and rat liver phosphatidylethanolamine (30 mole \%).

\section{INTRODUCTION}

The exchange of phospholipids between mitochondria and microsomes from rat liver is greatly stimulated by the $105000 \times g$ supernatant fraction ${ }^{1-5}$. If the $\mathrm{pH}$ of either the I05000 $\times g$ supernatant or a post-mitochondrial supernatant is adjusted to $5 . \mathrm{I}$, the stimulating activity is recovered in the ensuing supernatant, i.e. the $\mathrm{pH}$ 5.I supernatant ${ }^{4}$. A stimulating effect of the $\mathrm{pH}$ 5.I supernatant has been observed on the exchange of phospholipids between mitochondria and plasma lipoproteins $\mathbf{4}^{\mathbf{4} 6}$ and between mitochondria and artificially prepared phospholipid aggregates ${ }^{7}$. An active protein fraction denoted as phospholipid exchange protein was partially purified from the cytosol of beef heart ${ }^{8}$. To date, phospholipid exchange protein activity has been found in rat liver, heart, kidney and brain ${ }^{9}$, in beef liver and heart ${ }^{8}$, and in cauliflower and potato ${ }^{10}$. The physiological significance of the phospholipid exchange protein is not yet understood. Conceivably it does play a role in membrane

* Part of this investigation has been reported at the International Conference of Biological Membranes, Gargnano, Italy, June I97I. 
biogenesis by transferring phospholipid from the site of biosynthesis to the site of membrane development. Phospholipid exchange protein present in the cytosol of rat liver stimulates the exchange of both phosphatidylcholine, phosphatidylethanolamine and phosphatidylinositol ${ }^{9}$.

This investigation describes the isolation of a protein fraction from beef liver which specifically stimulates the exchange of phosphatidylcholine.

\section{MATERIALS AND METHODS}

\section{Preparation of membrane fractions}

Mitochondria and microsomes were isolated from male rats as described previously ${ }^{4}$. Radioactive subcellular fractions were obtained from rats injected intraperitoneally with either $300-500 \mu \mathrm{Ci}\left[{ }^{32} \mathrm{P}\right]$ phosphate (Philips Duphar, Amsterdam), or $20 \mu \mathrm{Ci}\left[M e^{-14} \mathrm{C}\right]$ choline (Radiochemical Center, Amersham) or $80 \mu \mathrm{Ci}\left[M e^{-3} \mathrm{H}\right]$ choline (Radiochemical Center, Amersham). Livers were excised $20 \mathrm{~h}$ after ${ }^{32} \mathrm{P}$ injection or $45 \mathrm{~min}$ after ${ }^{14} \mathrm{C}$ and ${ }^{3} \mathrm{H}$ administration. The latter time interval assures a specific labeling of phosphatidylcholine in the subcellular membrane fractions.

Liposomes were prepared in $0.25 \mathrm{M}$ sucrose-0.0oI M EDTA-0.or M Tris (pH 7.8) following the procedure of de Gier et al. ${ }^{11}$. The ensuing suspension was irradiated ultrasonically in a Branson Sonifier for $5 \mathrm{~min}$ at a roo Watt output and stored overnight in the refrigerator before use. Phosphatidylcholine was isolated from egg yolks according to the method of Papahadjopoulos and Miller ${ }^{12}$. Phosphatidylethanolamine was isolated from rat livers on a TEAE-cellulose column according to the method of Turner and Rouser ${ }^{13}$.

Protein was determined by the biuret method ${ }^{14}$ or by the method of Lowry et al. ${ }^{15}$. Lipid phosphorus was determined by the method of Chen et al. ${ }^{16}$ after destruction of the sample according to the procedure of Ames and Dubin ${ }^{17}$.

\section{Assay system $A$}

The assay is a slight modification of that described previously ${ }^{8}$. Mitochondria with ${ }^{32}$ P-labeled phospholipids (I2.5 $\mathrm{mg}$ protein), unlabeled microsomes $(2.5 \mathrm{mg}$ protein) and beef liver protein fractions were present in a total volume of $3 \mathrm{ml}$ sucroseEDTA-Tris buffer. Incubation was started by addition of the mitochondria as the last component and was carried out for $20 \mathrm{~min}$ at $25^{\circ} \mathrm{C}$. At the end of the incubation the mitochondria were sedimented at $10000 \times g$ for $5 \mathrm{~min}$ in the SS 34 rotor of the Sorvall centrifuge in Sorvall tubes (No. 250) with adapters. The phospholipids of the mitochondrial supernatant and of non-incubated ${ }^{32} \mathrm{P}$-labeled mitochondria were extracted according to the method of Bligh and Dyer ${ }^{18}$. Phosphatidylcholine was isolated and the specific radioactivity determined as described previously ${ }^{19}$. Controls without beef liver protein were carried through the entire procedure. The specific radioactivity, corrected for the control incubation, reflects the transfer of $\left[{ }^{32} \mathrm{P}\right]$ phosphatidylcholine from mitochondria to microsomes due to the presence of the phospholipid exchange protein (see Results and Discussion).

\section{Assay system $B$}

In this assay use was made of mitochondria containing ${ }^{14} \mathrm{C}$-labeled phosphatidylcholine. The incubation of mitochondrial and microsomal fractions was carried 
out as described for Assay A. After the incubation $2 \mathrm{ml}$ of the mitochondrial supernatant, containing the microsomes labeled with $\left[{ }^{14} \mathrm{C}\right]$ phosphatidylcholine as a result of the exchange process, were mixed with I $\mathrm{ml}$ of a microsomal suspension labeled with $\left[{ }^{3} \mathrm{H}\right]$ phosphatidylcholine. The ${ }^{3} \mathrm{H}$-labeled microsomes serve as an internal standard in the course of the following procedure. The phospholipids of the mixture were extracted according to the method of Bligh and Dyer ${ }^{18}$. The extract was concentrated to dryness in vacuo, dissolved in $0.3 \mathrm{ml}$ methanol and mixed with $\mathrm{I} 5 \mathrm{ml}$ of toluene (0.5\% PPO, $0.03 \%$ POPOP). Radioactivity was measured with a Packard Tricarb liquid scintillation spectrometer and the ${ }^{14} \mathrm{C} /{ }^{3} \mathrm{H}$ ratio of phosphatidylcholine radioactivity calculated. Controls without beef liver protein were carried through the entire procedure. The ${ }^{14} \mathrm{C} /{ }^{3} \mathrm{H}$ ratio corrected for the control incubation reflects the transfer of $\left[{ }^{14} \mathrm{C}\right]$ phosphatidylcholine from mitochondria to microsomes due to the presence of phospholipid exchange protein (see Results and Discussion).

\section{Determination of specificity}

In order to determine which class of phospholipids was stimulated by a particular beef liver protein fraction in the phospholipid exchange, the protein fraction was incubated with ${ }^{32} \mathrm{P}$-labeled microsomes and unlabeled mitochondria (Expt I), with ${ }^{32} \mathrm{P}$-labeled microsomes and liposomes (Expt 2) and with ${ }^{32} \mathrm{P}$-labeled mitochondria and liposomes (Expt 3). For incubation conditions, see legend to Table II. In Expt I, the mitochondria were sedimented at $10000 \times g$ for $5 \mathrm{~min}$ at the end of the incubation, washed twice with sucrose-EDTA-Tris buffer and resuspended in water. In Expt 2, the microsomes were sedimented at $105000 \times g$ for 60 min (angle rotor No. 5o, Spinco) at the end of incubation while in Expt 3 the mitochondria were sedimented at $10000 \times g$ for $5 \mathrm{~min}$. The pellets in the latter two experiments were discarded whereas the ensuing supernatant fractions containing the liposomes were isolated. The phospholipids were extracted from the resuspended mitochondria (Expt I), the liposomal suspensions (Expts 2 and 3) and aliquots of non-incubated ${ }^{32} \mathrm{P}$-labeled mitochondria and non-incubated ${ }^{32} \mathrm{P}-\mathrm{labeled}$ microsomes as described by Folch et al. ${ }^{20}$. Lipid phosphorus was determined and aliquots of the lipid extracts were applied to silica gel $\mathrm{H}$ thin-layer plates. The individual phospholipids were separated two-dimensionally following the procedure of Broekhuyse ${ }^{21}$. Lipids were detected by iodine vapour, the areas containing the lipids were scraped off in counting vials and the radioactivity determined. The distribution of ${ }^{32} \mathrm{P}$ among the individual phospholipids was calculated for the total subcellular phospholipid pool, originally present in the incubation medium. Control incubations without the beef liver protein fractions were carried through the entire procedure.

\section{RESULTS AND DISCUSSION}

\section{The assay systems}

Incubation of mitochondria labeled with $\left[{ }^{32} \mathrm{P}\right]$ phospholipid, and microsomes in the presence of a $105000 \times g$ supernatant fraction results in a transfer of $\left.{ }^{\left[{ }^{2}\right.} \mathrm{P}\right]$ phospholipid from the mitochondria to the microsomes and a concomittant transfer of unlabeled phospholipid from the microsomes to the mitochondria, i.e. in an exchange of phospholipid ${ }^{4}$. The extent of exchange is reflected in the decrease of specific radioactivity of the mitochondrial phospholipid and in the increase of specific radio- 
activity of the microsomal phospholipid. This change in specific radioactivity provides the basis for Assay system A (see Materials and Methods).

The exchange of phosphatidylcholine between ${ }^{32} \mathrm{P}$-labeled mitochondria and unlabeled microsomes as a function of phospholipid exchange protein activity is shown in Fig. I. The specific radioactivity of microsomal phosphatidylcholine, i.e. the exchange of phosphatidylcholine, increases linearly with increasing amounts of $\mathrm{pH}$ 5.I supernatant protein (starting material in the purification of phospholipid exchange protein) for a 20 min incubation. The specific radioactivity obtained after incubation without protein serves as a control in the assay.

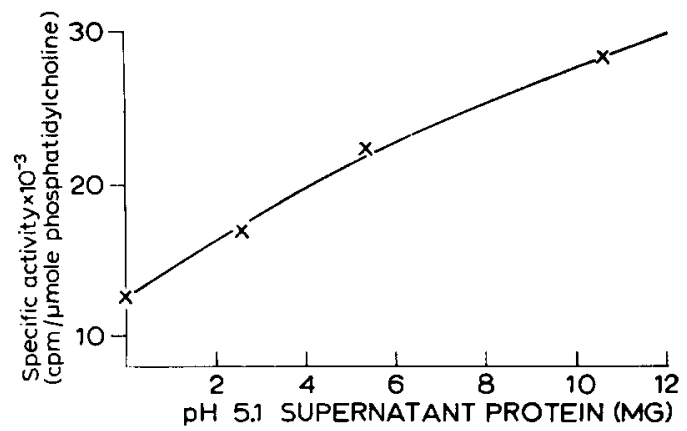

Fig. I. Transfer of $\left[{ }^{32} \mathrm{P}\right]$ phosphatidylcholine from ${ }^{32} \mathrm{P}$-labeled mitochondria to microsomes as reflected by the specific activity of microsomal phosphatidylcholine. Effect of various amounts of $\mathrm{pH}$ 5.I supernatant protein. The incubation was at $25^{\circ} \mathrm{C}$ for $20 \mathrm{~min}$. The incubation mixture contained $9.5 \mathrm{mg}$ mitochondrial protein ( $0.7 \mu$ mole phosphatidylcholine) and $2.6 \mathrm{mg}$ microsomal protein (0.9 $\mu$ mole phosphatidylcholine) in a total volume of $3 \mathrm{ml} 0.25 \mathrm{M}$ sucrose-0.00I M EDTAo.or M Tris ( $\mathrm{pH} 7.8$ ). The specific radioactivity of mitochondrial phosphatidylcholine was I $24800 \mathrm{cpm} / \mu \mathrm{mole}$

The $\mu$ moles of phosphatidylcholine transferred from the ${ }^{32} \mathrm{P}-\mathrm{labeled}$ mitochondria to the unlabeled microsomes per $\mathrm{mg} \mathrm{pH}$ 5.I supernatant protein per min of incubation can be calculated as follows (see also legend to Fig. I): The specific radioactivity of microsomal phosphatidylcholine, expressed in $\mathrm{cpm} / \mu \mathrm{mole}$, increases from $\mathrm{I} 2400$ to $\mathrm{I} 4200$ as a result of a 20 -min incubation with $\mathrm{I}$ mg protein. The incubation mixture contains $0.9 \mu$ moles of microsomal phosphatidylcholine. Therefore, 0.9 $(\mathrm{I} 4200-\mathrm{I} 2400)=\mathrm{I} 620 \mathrm{cpm}$ are present in the microsomal phosphatidylcholine due to the exchange in the presence of $\mathrm{I} \mathrm{mg}$ protein. Since the specific radioactivity of the mitochondrial phosphatidylcholine is $\mathrm{I} 24800 \mathrm{cpm} / \mu$ mole, $\mathrm{I} 620 / \mathrm{I} 24800=\mathrm{I}^{\cdot} \mathrm{IO}^{-3}$ $\mu$ moles phosphatidylcholine have actually been transferred to the microsomes. Because the exchange increases linearly with time for a $20-m i n$ incubation $^{19}$ it can be concluded that I $\mathrm{mg} \mathrm{pH}$ 5.I supernatant protein from beef liver stimulates the transfer of $13 \cdot 10^{-3} / 20=0.6 \cdot 10^{-3} \mu$ mole phosphatidylcholine from mitochondria to microsomes per min. A unit of phospholipid exchange protein activity is defined as the amount of protein which stimulates the transfer of $I \cdot I O^{-3} \mu$ mole phosphatidylcholine per $\mathrm{min}$. In this instance, therefore, I $\mathrm{mg} \mathrm{pH} \mathrm{5.I} \mathrm{supernatant} \mathrm{protein} \mathrm{has}$ 0.6 units of activity. This value varies from 0.4 to 0.6 units per mg protein depending on the batch. In the isolation of phospholipid exchange protein from beef liver, Assay B (see Materials and Methods) was routinely used. In Assay B, mitochondria labeled with $\left[{ }^{14} \mathrm{C}\right]$ phosphatidylcholine were incubated. In the presence of phospholipid 
exchange protein activity $\left[{ }^{14} \mathrm{C}\right]$ phosphatidylcholine is transferred from the mitochondria to the microsomes. The extent of $\left[{ }^{[14} \mathrm{C}\right]$ phosphatidylcholine transfer is a measure for the activity. At the end of the incubation, however, microsomes labeled with $\left[{ }^{3} \mathrm{H}\right]$ phosphatidylcholine are added as an internal standard to the mitochondrial supernatant containing the microsomes labeled with $\left[{ }^{14} \mathrm{C}\right]$ phosphatidylcholine. Addition of the internal standard makes the determination of the absolute amount of $\left.{ }^{14} \mathrm{C}\right]$ phosphatidylcholine radioactivity transferred to the microsomes unnecessary. The ${ }^{14} \mathrm{C} /{ }^{3} \mathrm{H}$ ratio of the phosphatidylcholine radioactivity is an index for the phospholipid exchange protein activity.

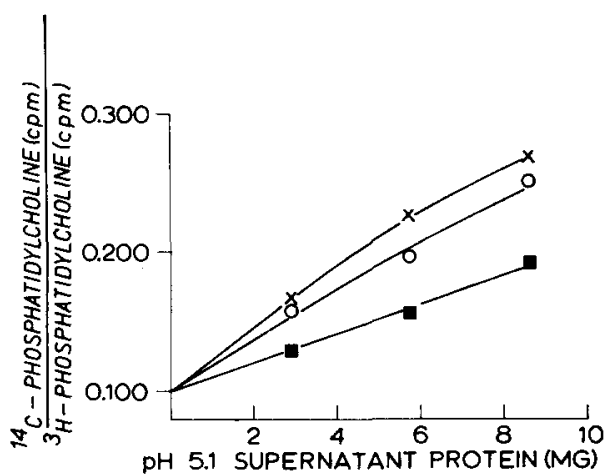

Fig. 2. Transfer of $\left[{ }^{14} \mathrm{C}\right]$ phosphatidylcholine from mitochondria labeled with $\left[{ }^{14} \mathrm{C}\right]$ phosphatidylcholine to microsomes as reflected by the ${ }^{14} \mathrm{C} /{ }^{3} \mathrm{H}$ ratio of radioactivity of microsomal phosphatidylcholine. Effect of various amounts of $\mathrm{pH}$ 5.I supernatant protein. The incubation was at $25^{\circ} \mathrm{C}$ for different times of incubation. The incubation mixture contained $12 \mathrm{mg}$ mitochondrial protein and $2.5 \mathrm{mg}$ microsomal protein in a total volume of $3 \mathrm{ml} 0.25 \mathrm{M}$ sucrose-o.oor M EDTA-o.or M Tris $(\mathrm{pH} 7.8)$. - $, 0-0, x-x ; 10,20$ and 30 min of incubation, respectively.

Fig. 2 shows to what extent the ${ }^{14} \mathrm{C} /{ }^{3} \mathrm{H}$ ratio depends upon time of incubation and amount of $\mathrm{pH}$ 5.I supernatant protein. For a short incubation period (Io min) the ratio increases linearly with increasing amounts of $\mathrm{pH}$ 5.I supernatant protein. Digression from this proportionality is observed at longer periods of incubation (30 $\mathrm{min})$. In the assay of the phospholipid exchange protein we routinely incubated for 20 min with less phospholipid exchange protein activity than is present in $6 \mathrm{mg}$ $\mathrm{pH}$ 5. I supernatant protein. The ${ }^{14} \mathrm{C} /{ }^{3} \mathrm{H}$ ratio obtained after incubation without beef liver protein, serves as a control in the assay. It followed from the succinate-cytochrome $c$ reductase activity ${ }^{22}$ which remained in the mitochondrial supernatant at the end of incubation that more than $99 \%$ of the mitochondria were sedimented. The transfer of labeled phosphatidylcholine in the control incubations of both assays might indicate that some exchange occurs without the intervention of the phospholipid exchange protein. The ${ }^{14} \mathrm{C} /{ }^{3} \mathrm{H}$ ratio of the phosphatidylcholine radioactivity can be correlated with the actual amount of $\left[{ }^{14} \mathrm{C}\right]$ phosphatidylcholine transferred in the following manner: a 20-min incubation with I $\mathrm{mg} \mathrm{pH}$ 5. I supernatant protein results in an increase of the ${ }^{14} \mathrm{C} /{ }^{3} \mathrm{H}$ ratio of $(0 . \mathrm{II} 8-0 . \mathrm{IOO})=0.0 \mathrm{I} 8$ (Fig. 2). It followed from Fig. I that I mg pH 5.I supernatant protein has 0.5 units of phospholipid exchange protein activity. Therefore, a $\Delta$ ratio of 0.018 after a 20 -min incubation corresponds to a transfer of $20 \cdot 0.5 \cdot 10^{-3}=I 0 \cdot 10^{-3} \mu$ mole phosphatidylcholine, i.e. 0.5 units of phospholipid exchange protein activity. 
Assay B gives directly the purification factor of a beef liver protein fraction in the purification of phospholipid exchange protein. Assay A, which is more timeconsuming, is necessary to calculate the actual units of activity. As for accuracy, both assays give comparable results.

\section{Purification of the phospholipid exchange protein}

All manipulations during the isolation were performed at $4{ }^{\circ} \mathrm{C}$. The different steps of the purification are summarized in Table I.

\section{TABLE I}

PURIFICATION OF PHOSPHOLIPID EXCHANGE PROTEIN FROM BEEF LIVER

\begin{tabular}{lccccc}
\hline Step & $\begin{array}{l}\text { Volume } \\
(\mathrm{m} l)\end{array}$ & $\begin{array}{l}\text { Protein } \\
(\mathrm{mg})\end{array}$ & $\begin{array}{l}\text { Specific } \\
\text { activity }\end{array}$ & $\begin{array}{l}\text { Recovery } \\
(\%)\end{array}$ & $\begin{array}{l}\text { Purification } \\
\text { factor }\end{array}$ \\
\hline I. pH adjustment & 1000 & 28 ooo & 0.5 & 100 & - \\
2. DEAE-Sephadex A-5o & 1220 & 2920 & 2.5 & 52 & 5 \\
3. $\left(\mathrm{NH}_{4}\right)_{2} \mathrm{SO}_{4}$ precipitation & 75 & 2070 & 3.5 & 52 & 7 \\
4. Sephadex G-75 & 262 & 65 & 70 & 33 & 140 \\
5. $\left(\mathrm{NH}_{4}\right)_{2} \mathrm{SO}_{4}$ precipitation & 7 & 36 & 110 & 28 & 220 \\
6. Sephadex G-50 & 43 & 14 & 155 & 15 & 310 \\
\hline
\end{tabular}
protein.

${ }^{\star}$ Specific activity is expressed as units of phospholipid exchange protein activity per mg

Step $I$. Fresh beef liver (Iooo g) was cut in small pieces and then washed with I 1 of $0.25 \mathrm{M}$ sucrose. A $30 \%$ homogenate in $0.25 \mathrm{M}$ sucrose was prepared with a Waring Blendor (I min at high speed). Nuclei and cell debris were removed by centrifugation in the International PR- 6 centrifuge ( 15 min at $600 \times g$ ). The supernatant was centrifuged in the GSA rotor of the Sorvall centrifuge to sediment mitochondria and lysosomes $(20 \mathrm{~min}$ at $\mathrm{I} 5000 \times \mathrm{g}$ ). The $\mathrm{pH}$ of the supernatant was adjusted to 5.I with $3 \mathrm{M} \mathrm{HCl}$. The precipitate was sedimented by centrifugation in the Sorvall centrifuge ( $15 \mathrm{~min}$ at $\mathrm{I} 5000 \times \mathrm{g}$ ) and discarded. After addition of Tris $(0.05 \mathrm{M}$ ) and $\beta$-mercaptoethanol (o.oI $\mathrm{M}$ ) the $\mathrm{pH}$ of the solution was readjusted to 8.4 with $3 \mathrm{M} \mathrm{HCl}$.

Step 2. $28 \mathrm{~g}$ of the protein (Iooo $\mathrm{ml}$ ) were applied to a DEAE-Sephadex A-50 column (Pharmacia Fine Chemicals). Elution was started with o.I M Tris-HCl-o.or M $\beta$-mercaptoethanol ( $\mathrm{pH}$ 8.4). Some phospholipid exchange protein activity was present in the unabsorbed protein fraction. The bulk of the phospholipid exchange protein activity, however, appeared in the effluent after the ionic strength of the eluting buffer was increased with $\mathrm{NaCl}(0.05 \mathrm{M})$. A typical elution pattern is given in Fig. 3. The effluents with a specific activity of about 2.5 were combined. The yield was $52 \%$.

Step 3. Solid $\left(\mathrm{NH}_{4}\right)_{2} \mathrm{SO}_{4}(65 \mathrm{~g} / 100 \mathrm{ml})$ was added to precipitate the active protein. The precipitate was dissolved in a minimal volume of o.or $\mathbf{M}$ sodium phosphate-o.or $\mathrm{M} \beta$-mercaptoethanol ( $\mathrm{pH} 7.8$ ) and dialysed overnight against 5o vol. of the same buffer. This treatment did not affect the yield while a 7 -fold purification was obtained.

Step 4. $700 \mathrm{mg}$ protein were applied to a Sephadex G-75 column (Pharmacia Fine Chemicals). The eluting buffer was o.or M sodium phosphate-o.or M $\beta$-mercap- 
toethanol ( $\mathrm{pH}$ 7.8). A typical elution pattern is given in Fig. 4. The fractions with a specific activity above 20 were combined (tubes Nos 25-32). The combined fraction was purified I40-fold. The yield was $33 \%$.

Step 5. The pooled fractions were treated with $\left(\mathrm{NH}_{4}\right)_{2} \mathrm{SO}_{4}$ as described in Step 3 . This concentration step barely affected the yield while the protein was 220 -fold purified.

Step 6. I $8 \mathrm{mg}$ protein were applied to a Sephadex G-50 column (Pharmacia Fine Chemicals). The protein fractions were eluted with the phosphate-mercaptoethanol

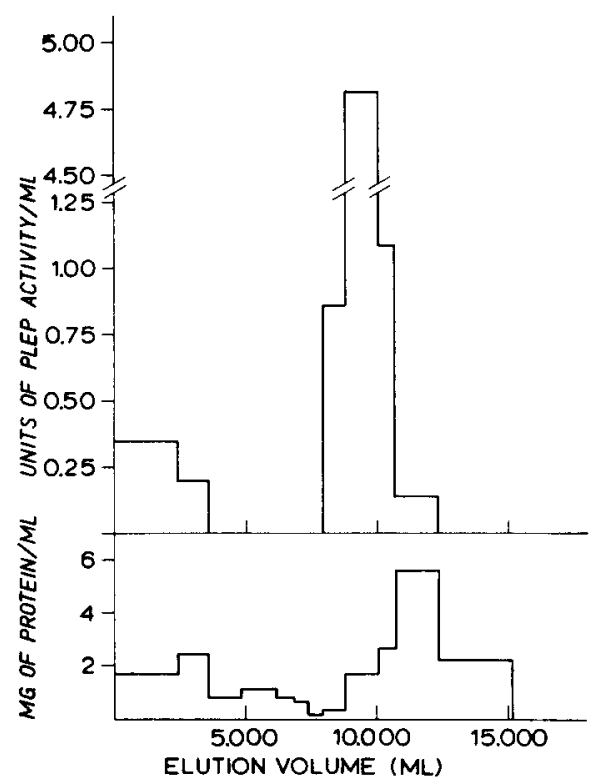

Fig. 3. Elution pattern of phospholipid exchange protein (PLEP) from a DEAE-Sephadex A-50 column $\left(5^{8} \mathrm{~cm} \times 6.5 \mathrm{~cm}\right) .28 \mathrm{~g} \mathrm{pH} 5 . \mathrm{I}$ supernatant protein were applied to column. Eluting buffer was o.I M Tris-HCl-o.oI M $\beta$-mercaptoethanol ( $\mathrm{pH} 8.4$ ). After 71 of the buffer, elution was continued with 7 l o.r M Tris-HCl-o.or M $\beta$-mercaptoethanol-0.05 M NaCl (pH 8.4). Flowrate, $60 \mathrm{ml} / \mathrm{h}$. Protein was determined according to the method of Lowry ${ }^{15}$.

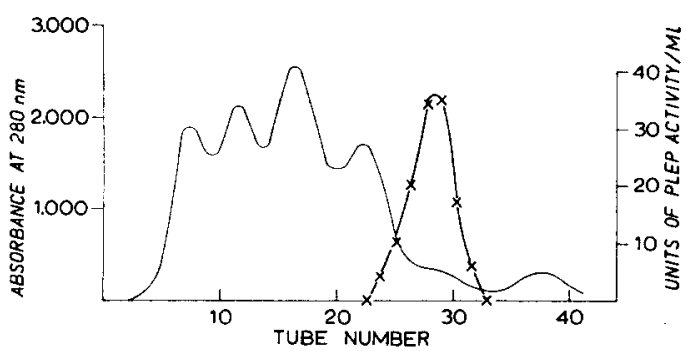

Fig. 4. Elution pattern of phospholipid exchange protein (PLEP) from a Sephadex G-75 column $(72 \mathrm{~cm} \times 5 \mathrm{~cm}) .700 \mathrm{mg}$ protein were applied to column. Eluting buffer was o.or M phosphateo.or M $\beta$-mercaptoethanol ( $\mathrm{pH} 7.8$ ). Flowrate, $24 \mathrm{ml} / \mathrm{h}$. I2- $\mathrm{ml}$ fractions were collected. Elution of protein was determined by measuring absorbance at $280 \mathrm{~nm} . \times-x$, units of phospholipid exchange protein activity per $\mathrm{ml}$ effluent. 
buffer. Phospholipid exchange protein activity was present in the second peak (Fig. 5). The fractions with a specific activity above Ioo were combined (tubes Nos I2-I5). This final step resulted in a 300 -fold purified protein. The recovery of activity amounted to $15 \%$.

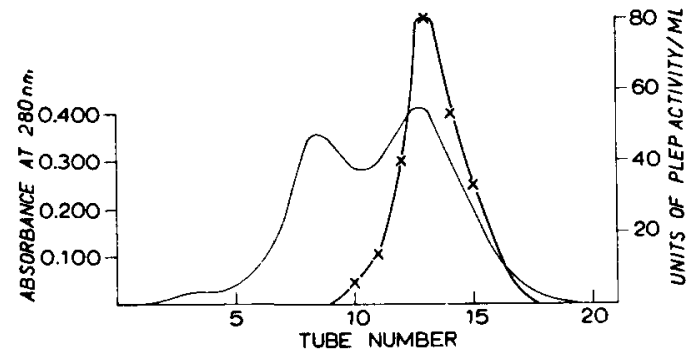

Fig. 5. Elution pattern of phospholipid exchange protein (PLEP) from a Sephadex G-5o column (I $55 \mathrm{~cm} \times 2 \mathrm{~cm}$ ). I $8 \mathrm{mg}$ protein were applied to column. Eluting buffer was $0.01 \mathrm{M}$ phosphateo.or M $\beta$-mercaptoethanol ( $\mathrm{pH} 7.8$ ). Flowrate, $7 \mathrm{ml} / \mathrm{h} .3 \cdot 5$-ml fractions were collected. Elution of protein was determined by measuring absorbance at $280 \mathrm{~nm}$. $\times-\times$, units of phospholipid exchange protein activity per ml effluent.

The purity of the phospholipid exchange protein was checked with disc gel electrophoresis on polyacrylamide as described by Ornstein and Davis ${ }^{23}$. Phospholipid exchange protein of comparable specific activities consisted of one component in one purification whereas as many as four components were found in another purification. To date it is not known what causes this difference.

\section{Some properties of the phospholipid exchange protein}

A molecular weight of 22000 was calculated from the eluting $\left(V_{\mathrm{e}}\right)$ and void $\left(V_{\mathrm{o}}\right)$ volume after chromatography on Sephadex G-75. The equation $\log M_{\mathrm{r}}=5.624-0.752$ $\left(V_{\mathrm{e}} / V_{\mathrm{o}}\right)$ derived by Determann ${ }^{24}$ for Sephadex G-75 was applied. $M_{\mathrm{r}}$ is the molecular weight of the protein. Phospholipid exchange protein stored in $50 \%$ glycerol at $-20{ }^{\circ} \mathrm{C}$ retained its full activity for at least $\mathrm{I}$ month. Storage of phospholipid exchange protein in o.or $\mathrm{M}$ sodium phosphate-o.or $\mathrm{M} \beta$-mercaptoethanol ( $\mathrm{pH} 7.8$ ) overnight at $-20{ }^{\circ} \mathrm{C}$ resulted in a complete loss of activity. Phospholipid exchange protein retained $80 \%$ of its activity after Io min incubation at $60{ }^{\circ} \mathrm{C}$. Incubation of the protein at $70^{\circ} \mathrm{C}$ for Io min caused a complete inactivation.

\section{Specificity of phospholipid exchange protein}

By extending Assay $A$ to the exchange of phosphatidylethanolamine and phosphatidylinositol, the $\mathrm{pH}$ 5.I supernatant protein from rat liver was found to stimulate the exchange of phosphatidylcholine, phosphatidylethanolamine and phosphatidylinositol between mitochondria and microsomes ${ }^{8}$. In Assay B, however, only the transfer of $\left[{ }^{14} \mathrm{C}\right]$ phosphatidylcholine was measurable between these subcellular particles. In as much as the latter assay was used routinely, it was feasible that the purified phospholipid exchange protein also stimulated the exchange of phosphatidylethanolamine and phosphatidylinositol. By measuring the transfer of $\left[{ }^{32} \mathrm{P}\right]$ phospholipid from ${ }^{32} \mathrm{P}$-labeled subcellular membranes to unlabeled membranes in the presence of either the $\mathrm{pH}$ 5.I supernatant protein or the purified protein factor 
from beef liver, the specificity of these proteins in the phospholipid exchange was assessed (see Materials and Methods). The extent of $\left[{ }^{32} \mathrm{P}\right]$ phospholipid transfer is expressed as the percentage of $\left[{ }^{32} \mathrm{P}\right]$ phospholipid present in the ${ }^{\mathbf{3 2}} \mathrm{P}$-labeled particles before incubation.

The pH 5.I supernatant protein stimulates the transfer of both $\left[{ }^{32} \mathrm{P}\right]$ phosphatidylcholine, [ $\left.{ }^{32} \mathrm{P}\right]$ phosphatidylinositol and $\left[{ }^{32} \mathrm{P}\right]$ phosphatidylethanolamine from ${ }^{32}$ P-labeled microsomes to unlabeled mitochondria (Expt I, Table II). The transfer of $\left[{ }^{32} \mathrm{P}\right]$ phosphatidylethanolamine is the least extensive, again confirming previous results ${ }^{1,19}$. The purified phospholipid exchange protein, however, was found to stimulate exclusively the transfer of $\left[{ }^{32} \mathrm{P}\right]$ phosphatidylcholine. This specificity is also apparent in the exchange between ${ }^{32} \mathrm{P}$-labeled microsomes and egg yolk phosphatidylcholine liposomes (Expt 2) and in the exchange between ${ }^{32}$ P-labeled mitochondria and liposomes consisting of 70 mole \% egg yolk phosphatidylcholine and 30 mole \% rat liver phosphatidylethanolamine (Expt 3). It follows from these experiments that the $\mathrm{pH}$ 5.I supernatant stimulates the transfer of both [ $\left.{ }^{32} \mathrm{P}\right]$ phosphatidylcholine, [ $\left.{ }^{32} \mathrm{P}\right]$ phosphatidylinositol and $\left[{ }^{32} \mathrm{P}\right]$ phosphatidylethanolamine to the liposomes although the latter two phospholipids were lacking in those liposomes. It is hard to determine whether we are dealing in this instance with net transport of those

\section{TABLE II}

EFFECT OF $\mathrm{pH}$ 5.I SUPERNATANT PROTEIN AND PHOSPHOLIPID EXCHANGE PROTEIN ON THE EXCHANGE OF THE INDIVIDUAL PHOSPHOLIPIDS

The incubations were in a total volume of $3 \mathrm{ml} 0.25 \mathrm{M}$ sucrose-0.00I M EDTA-0.01 M Tris (pH 7.8). Expt I: $2.85 \mathrm{mg}{ }^{32} \mathrm{P}$-labeled microsomes ( $.8 \mu$ moles phospholipid) and $12.0 \mathrm{mg}$ mitochondria $(2.0 \mu$ moles phospholipid) were incubated with $3.7 \mathrm{mg} \mathrm{pH} 5.1$ supernatant protein or $0.028 \mathrm{mg}$ phospholipid exchange protein (Step 6) for $40 \mathrm{~min}$ at $37{ }^{\circ} \mathrm{C}$. Expt $2: 2.15 \mathrm{mg}{ }^{32} \mathrm{P}$-labeled microsomes (I.4 $\mu$ moles phospholipid) and egg yolk phosphatidylcholine liposomes (o.9 $\mu$ mole phospholipid) were incubated with $5 \mathrm{mg} \mathrm{pH}$ 5.I supernatant protein or $0.027 \mathrm{mg}$ phospholipid exchange protein (Step 6) for $4^{\circ} \mathrm{min}$ at $25^{\circ} \mathrm{C}$. Expt 3: r2.5 $\mathrm{mg}{ }^{32} \mathrm{P}$-labeled mitochondria (2.0 $\mu$ moles phospholipid) and egg yolk phosphatidylcholine (7o mole \%)-rat liver phosphatidylethanolamine $(30$ mole \%) liposomes (I.4 $\mu$ moles phospholipid) were incubated with $5.6 \mathrm{mg}$ $\mathrm{pH}$ 5. I supernatant protein or $0.029 \mathrm{mg}$ phospholipid exchange protein (Step 6) for $20 \mathrm{~min}$ at $25^{\circ} \mathrm{C}$.

\begin{tabular}{|c|c|c|c|c|c|}
\hline \multirow[t]{2}{*}{ Expt } & \multicolumn{2}{|c|}{ Incubation mixture } & \multicolumn{3}{|c|}{$\begin{array}{l}\text { Distribution of total }{ }^{32} P \\
\text { in individual phospholipids }{ }^{\star \star}(c p m)\end{array}$} \\
\hline & $\begin{array}{l}\text { Membrane } \\
\text { fraction }\end{array}$ & Protein fraction & $\begin{array}{l}\text { Phosphatidyl- } \\
\text { choline }\end{array}$ & $\begin{array}{l}\text { Phosphatidyl- } \\
\text { inositol }\end{array}$ & $\begin{array}{l}\text { Phosphatidyl- } \\
\text { ethanolamine }\end{array}$ \\
\hline I & $\begin{array}{l}\text { Microsomes } \\
\text { Mitochondria } \\
\text { Mitochondria }\end{array}$ & $\begin{array}{l}\mathrm{pH} \text { 5.I supernatant } \\
\text { Exchange protein }\end{array}$ & $\begin{array}{rl}52 & 870 \\
7078(13.4 \%) \\
7236(\text { I } 3.7 \%)\end{array}$ & $\begin{array}{l}\text { I } 690 \\
\text { I } 76(\text { I } 0.4 \%) \\
\text { I } 8(\text { I.I } \%)\end{array}$ & $\begin{array}{l}\text { I } 594^{\circ} \\
454(2.9 \%) \\
\text { I } 4(0.1 \%)\end{array}$ \\
\hline 2 & $\begin{array}{l}\text { Microsomes } \\
\text { Liposomes } \\
\text { Liposomes }\end{array}$ & $\begin{array}{l}\text { pH 5.I supernatant } \\
\text { Exchange protein }\end{array}$ & $\begin{array}{rl}23 & 769 \\
3 & 759(\text { I } 5.8 \%) \\
4 & \text { I } 86(\text { ( } 7.6 \%)\end{array}$ & $\begin{array}{rr}2293 & \\
99 & (4.3 \%) \\
9 & (0.4 \%)\end{array}$ & $\begin{array}{c}9898 \\
558(5.7 \%) \\
5(0 \%)\end{array}$ \\
\hline 3 & $\begin{array}{l}\text { Mitochondria } \\
\text { Liposomes } \\
\text { Idiposomes }\end{array}$ & $\begin{array}{l}\text { pHI 5.I supernatant } \\
\text { Exchange protein }\end{array}$ & $\begin{array}{rr}57050 & \\
5427 & (9.5 \%) \\
5624 & (9.9 \%)\end{array}$ & $\begin{array}{rr}4791 & \\
303 & (6.3 \%) \\
18 & (0.4 \%)\end{array}$ & $\begin{array}{r}4^{8} 45^{\circ} \\
+239(2.6 \%) \\
278(0.6 \%)\end{array}$ \\
\hline
\end{tabular}

* The figures in the table are corrected for the control incubation.

** The figures in parentheses are the percent of microsomal ${ }^{32} \mathrm{P}$ radioactivity transferred to either mitochondria or liposomes (Expts $x$ and 2). 
phospholipids or with an actual exchange of those phospholipids with liposomal phosphatidylcholine. The reason for uncertainty is that the transfer is very little in terms of chemical phospholipid. In Expt 2, for example, I.4 $\mu$ mole microsomal phospholipid, present in the incubation, consists of $0.14 \mu$ mole phosphatidylinositol and $0.35 \mu$ mole phosphatidylethanolamine. $5 \mathrm{mg} \mathrm{pH} 5 . \mathrm{I}$ supernatant protein stimulated the transfer of $4 \%$ microsomal phosphatidylinositol $(=0.006 \mu$ mole $)$ and $6 \%$ microsomal phosphatidylethanolamine $(=0.02 \mathrm{I} \mu \mathrm{mole})$. This amount of phospholipid is only $3 \%$ of the $0.9 \mu$ mole liposomal phosphatidylcholine present in the incubation to start with. However, we observed consistently that the transfer of $\left[{ }^{32} \mathrm{P}\right] \mathrm{phospha}-$ tidylinositol and $\left[{ }^{32} \mathrm{P}\right]$ phosphatidylethanolamine between subcellular membranes and liposomes was of the same order of magnitude as the transfer of those phospholipids between mitochondria and microsomes in the presence of $\mathrm{pH}$ 5.I supernatant protein (see Table II).

Since the purified phospholipid exchange protein stimulated only the exchange of phosphatidylcholine, the various fractions from the DEAE-Sephadex A-5o column were checked for their capability to stimulate the exchange of phosphatidylinositol and phosphatidylethanolamine between ${ }^{32} \mathrm{P}$-labeled microsomes and mitochondria (see Fig. 3). It turns out that the active fraction eluted from the column at the higher ionic strength is already specific for phosphatidylcholine. The only other fraction which showed phospholipid exchange activity, was found in the void volume. This fraction stimulated the exchange of both phosphatidylcholine, phosphatidylinositol and phosphatidylethanolamine. It follows from Table III that the protein in the void volume stimulates the exchange of phosphatidylinositol and phosphatidylethanolamine somewhat better than the $\mathrm{pH}$ 5.I supernatant protein and the exchange of phosphatidylcholine to a lesser extent.

\section{TABLE III}

EFFECT OF $\mathrm{pH}$ 5.I SUPERNATANT PROTEIN AND VOTD VOLUME PROTEIN FROM DEAE-SEPHADEX A-5O COLUMN ON THE EXCHANGE OF THE INDIVIDUAL PHOSPHOLIPIDS

$2.5 \mathrm{mg}$ microsomal protein (I.6 $\mu$ moles phospholipid) and $1 \mathrm{I} .5 \mathrm{mg}$ mitochondrial protein (I.9 $\mu$ moles phospholipid) were incubated with either $5.9 \mathrm{mg} \mathrm{pH} 5.1$ supernatant protein or $5.9 \mathrm{mg}$ protein, appearing in the void volume of the DEAE-Sephadex A-50 column. Incubation was in $3 \mathrm{ml} 0.25 \mathrm{M}$ sucrose-o.oor M EDTA-0.or M Tris $\left(\mathrm{pH}_{7.8}\right.$ ) for $4^{\circ}$ min at $25^{\circ} \mathrm{C}$. Experimental details are identical to those of Expt I, Table II.

Incubation mixture

Membrane Protein fraction

fraction

Protein fraction

Microsomes

Mitochondria

Mitochondria
pH 5.I supernatant

void volume protein
Distribution of total ${ }^{32} P$

in individual phospholipids ${ }^{\star}$ * $(c p m)$

$\begin{array}{lll}\begin{array}{l}\text { Phosphatidyl- } \\ \text { choline }\end{array} & \begin{array}{l}\text { Phosphatidyl- } \\ \text { inositol }\end{array} & \begin{array}{l}\text { Phosphatidyl- } \\ \text { ethanolamine }\end{array}\end{array}$

${ }^{\star}, * \star$ See footnotes to Table II. 
A protein fraction is isolated from the cytosol of beef liver which specifically stimulates in vitro the exchange of phosphatidylcholine between mitochondria and microsomes from rat liver. If either mitochondria or microsomes were replaced by liposomes the purified protein maintained its specificity for phosphatidylcholine. Although the mode of action of phospholipid exchange protein is not known, an interaction of the protein with subcellular membranes and liposomes is likely to occur. In this respect it is worth mentioning that negatively charged phospholipids inhibit the exchange of phosphatidylcholine between mitochondria and phosphatidylcholine liposomes. Phosphatidic acid, phosphatidylinositol and cardiolipin, either incorporated into the phosphatidylcholine liposome or added as a negatively charged liposome to the complete incubation mixture, showed this inhibitory effect (K.W.A. Wirtz, unpublished observations).

After chromatography of the $\mathrm{pH}$ 5. I supernatant protein on a DEAE-Sephadex A-5o column, only the protein in the void volume was found to stimulate the exchange of phosphatidylinositol and phosphatidylethanolamine. The bulk of the phosphatidylcholine exchange activity eluted from the column after the ionic strength of the eluting buffer was increased. Whether or not proteins are present in the cytosol which stimulate specifically the exchange of phosphatidylinositol and phosphatidylethanolamine, remains to be established. It is generally observed that the exchange of phosphatidylethanolamine is a slow process compared to that of phosphatidylcholine. This could mean that phosphatidylethanolamine is more firmly embedded in the membrane than phosphatidylcholine. On the other hand it is possible that a phosphatidylethanolamine-specific phospholipid exchange protein has a low activity in the cytosols which we have tested so far.

The exchange of phospholipids between the various subcellular membrane fractions of the rat liver in vivo is a very likely event ${ }^{\mathbf{2 5}, \mathbf{2 6}}$. This exchange could be fundamental to a net transport of phospholipid from the site of phospholipid biosynthesis, i.e. the endoplasmic reticulum to those sites in the cell which are deficient in phospholipid. Then it has to be assumed that a one-for-one exchange of phospholipid molecules is not necessary. The exchange of phospholipid could be the basic phenomenon on which the net transport of phospholipid is superimposed. The phospholipid exchange protein might be instrumental in this process in as much as it makes the exchange of phospholipid possible. If this is true the protein will be intimately involved in membrane biogenesis and phospholipid turnover. The exchange of phospholipids between the various membrane fractions is obviously controlled since many of the subcellular membranes have a distinct phospholipid composition ${ }^{27}$.

\section{ACKNOWLEDGMENTS}

The authors thank Mr P. de Jong and Miss H. M. A. Corbey for their contribution to some of the experiments. The technical assistance of Miss A. Niemeijer is greatly appreciated. 


\section{REFERENCES}

K. W. A. Wirtz and D. B. Zilversmit, J. Biol. Chem., 243 (1968) 3596.

2 W. C. McMurray and R. M. C. Dawson, Biochem. J., II 2 (1969) 9 I.

3 M. Akiyama and T. Sakagami, Biochim. Biophys. Acta, 187 (1969) 105.

4 K. W. A. Wirtz and D. B. Zilversmit, Biochim. Biophys. Acta, I93 (1969) I05.

5 L. Wojtczak, J. Baranska, J. Zborovski and Z. Drahota, Biochim. Biophys. Acta, 249 (197I) 4 I.

6 D. B. Zilversmit, J. Lipid Res., I2 (1971) 36.

7 D. B. Zilversmit, J. Biol. Chem., 246 (197I) 2645.

8 K. W. A. Wirtz and D. B. Zilversmit, FEBS Lett., 7 (1970) 44.

9 K. W. A. Wirtz, Thesis, Utrecht I97I, p. 39.

Io A. B. Abdelkader and P. Mazliak, Eur. J. Biochem., 15 (1970) $25^{\circ}$.

1 I J. de Gier, J. G. Mandersloot and L. L. M. van Deenen, Biochim. Biophys. Acta, I5o (1968) 666.

I 2 D. Papahadjopoulos and N. Miller, Biochim. Biophys. Acta, I35 (1967) 624 .

13 J. D. Turner and G. Rouser, Anal. Biochem., 38 (1970) 423.

14 A. G. Gornall, C. J. Bardawill and M. M. David, J. Biol. Chem., I 77 (I949) 75 I.

I5 O. H. Lowry, N. J. Rosebrough, A. L. Farr and R. J. Randall, J. Biol. Chem., I93 (195I) 265.

I6 A. S. Chen, T. Y. Toribara and H. Warner, Anal. Chem., 28 (I956) 1756.

I 7 R. N. Ames and D. T. Dubin, J. Biol. Chem., 235 (1960) 769.

I8 E. G. Bligh and W. J. Dyer, Can. J. Biochem. Physiol., 37 (1959) 9 I I.

I9 M. C. Blok, K. W. A. Wirtz and G. L. Scherphof, Biochim. Biophys. Acta, 233 (r97 I) 61.

20 J. Folch, M. Lees and G. H. Sloane-Stanley, J. Biol. Chem., 226 (I957) 497.

2 I R. M. Broekhuyse, Biochim. Biophys. Acta, I52 (I968) 307.

22 H. D. Tisdale, in S. P. Colowick and N. O. Kaplan, Methods in Enzymology, Vol. 1o, Academic

Press, New York, 1967, p. 213.

23 L. Ornstein and B. J. Davis, Ann. N.Y. Acad. Sci., I2I (I964) 305.

24 H. Determann, Gel Chromatography, Springer Verlag, New York, I969, p. I I I.

25 K. W. A. Wirtz and D. B. Zilversmit, Biochim. Biophys. Acta, 187 (1969) 468.

26 F. B. Jungalwala and R. M. C. Dawson, Biochem. J., II7 (1970) 481 .

27 A. Colbeau, J. Nachbaur and P. M. Vignais, Biochim. Biophys. Acta, 249 (I97I) 462.

Biochim. Biophys. Acta, 274 (1972) 606-61 7 